\title{
Chemical composition of the essential oil of Ocimum tenuiflorum L. (Krishna Tulsi) from North West Karnataka, India
}

\author{
R. K. Joshi ${ }^{1} \otimes$ \& S. L. Hoti ${ }^{2}$
}

\begin{abstract}
The chemical composition of the essential oil of flowering aerial parts of Ocimum tenuiflorum $L$. growing in the North West Karnataka, India, was investigated. The hydro-distilled essential oil was analyzed by gas chromatography equipped with flame ionization detector (GC-FID) and gas chromatography coupled with mass spectrometry (GC/MS). Results demonstrated that the oil was found to be rich in phenyl derivative compounds $(83.8 \%)$. The major compound was identified as methyl eugenol (82.9\%) among twenty-six compounds, comprising $98.9 \%$ of the total oil.
\end{abstract}

Keywords: Ocimum tenuiflorum; Lamiaceae; essential oil composition; methyl eugenol; GC/MS.

\section{Introduction}

Ocimum tenuiflorum L. (syn. Ocimum sanctum L.) of the family Lamiaceae is an erect, softly hairy, aromatic herb. The plant is commonly cultivated in temple premises and households as a sacred plant (Yadav \& Sardesai, 2002). Two types of 0 . tenuiflorum are met within cultivation: (i) with green leaves known as Sri or Lakshmi Tulsi and (ii) with purple leaves known as Krishna Tulsi (Pandey, 1990). In Ayurveda, this plant has been well documented for its

Received: 10 May 2014 / Accepted: 13 June 2014 / Published online: 1 July 2014

(C) Horizon e-Publishing Group

\section{CITATION}

Joshi, R. K., \& Hoti, S. L. (2014). Chemical composition of the essential oil of Ocimum tenuiflorum L. (Krishna Tulsi) from North West Karnataka, India. Plant Science Today, 1(3), 99-102. http://dx.doi.org/10.14719/pst.2014.1.3.52

\section{AUTHORS' AFFILIATION}

1 Department of Phytochemistry, Regional Medical Research Centre (Indian Council of Medical Research), Belgaum, Karnataka-590 010, India.

2 Regional Medical Research Centre (Indian Council of Medical Research), Belgaum, Karnataka-590 010, India.

■CORRESPONDENCE: R. K. Joshi. E-mail: joshirk_natprod@yahoo.com therapeutic potentials and described as Dashemani Shwasaharni (antiasthmatic) and antikaphic drugs (Kaphaghna) (Sirkar, 1989). Anticancer (Kathiresan, Guanasekan, Rammurthy, \& Govidswami, 1999), radioprotective, anticarcinogenic (Devi, 2001), antioxidant (Devi, 2001; Joshi, 2013a), chemopreventive (Prashar, Kumar, Banerjee, \& Rao, 1994; Karthikeyan, Ravichadran, \& Govindasamy, 1999), immunotherapeutic (Mukherjee, Das, \& Ram, 2005), antimicrobial (Singh, Malhotra, \& Majumdar, 2005; Joshi, 2013a), anti-inflammatory (Godhwani, Godhwani, \& Vyas, 1987; Singh \& Majumdar, 1997), analgesic, antipyretic (Godhwani et al., 1987), antispermatogenic (Seth, Johri, \& Sundaram, 1981) and antistress (Bhargava \& Singh, 1981) activities of this plant have also been reported. The essential oils of $O$. tenuiflorum have been reported to possess methyl eugenol (Joshi, 2013a), methyl eugenol, $\beta$-caryophyllene (Bhattacharya, Kaul, \& Rajeswara Rao, 1996; Kothari, Bhattacharya, Ramesh, Garg, \& Khanuja, 2005), methyl eugenol, (E)-caryophyllene, eugenol and, $\beta$-elemene (Awasthi \& Dixit, 2007), methyl chavicol, and linalool (Khan et al., 2010) from India; $\beta$-bisabolene, 1,8-cineole and methyl chavicol (Kicel, Kurowska, \& Kalemba, 2005) from Poland; methyl eugenol and isocaryophyllene (Gbolade \& Lockwood, 2008) from Nigeria; eugenol, $\beta$-caryophyllene and caryophyllene oxide (Machado, Silva, Matos, Craveiro, \& Alencar, 1999) from Northeastern Brazil; eugenol, $\beta$-elemene and $\beta$-caryophyllene (Pino, Rosado, Rodriguez, \& Garcia, 1998) from Cuba; methyl chavicol, camphor and $\beta$-caryophyllene (Brophy, Goldsack, \& Clarkson, 1993) from Australia. The aim of the present study was to investigate the essential oil composition of 0 . tenuiflorum (Krishna Tulsi) growing in North West Karnataka, India, using gas chromatography (GC) and gas chromatography-mass spectrometry (GC-MS) analyses.

\section{Materials and Methods}

\section{Plant Material}

The plant was collected in the month of January 2011 from 
Sankeshwar (N 16²7'470"; E 74²9'081") of district Belgaum, Karnataka, India, at an elevation of $\sim 653 \mathrm{~m}$. The plant was identified by Dr. H. V. Hegde, Taxonomist, Regional Medical Research Centre (RMRC), Belgaum (voucher specimen No. RMRC-1251).

\section{Isolation of essential oil}

The flowering aerial parts (100 g) were chopped into small pieces and subjected to hydro-distillation $(1500 \mathrm{~mL}$ distilled water $+100 \mathrm{~g}$ plant material in $3000 \mathrm{~mL}$ round bottom flask) using a Clevenger type apparatus for $3 \mathrm{~h}$ (Joshi, 2013b; Joshi \& Badakar, 2012). The oil was trapped by adding of $n$-hexane and dried over anhydrous $\mathrm{Na}_{2} \mathrm{SO}_{4}$ and kept in a sealed vial at $-4^{\circ} \mathrm{C}$ until analysis. The yield of oil was $0.2 \%, \mathrm{w} / \mathrm{w}$.

\section{GC and GC-MS analysis}

The analysis of oil was achieved using Varian 450 Gas Chromatograph (GC) equipped with a fused silica CP-Sil 8 CB capillary column $(30 \mathrm{~m} \times 0.25 \mathrm{~mm} ; 0.25 \mathrm{~m}$ film thickness) and flame ionization detector. The carrier gas was nitrogen at $1.0 \mathrm{~mL} / \mathrm{min}$ flow rate. The initial oven temperature was $60^{\circ} \mathrm{C}$ which was raised to $220^{\circ} \mathrm{C}$ with $3^{\circ} \mathrm{C} / \mathrm{min}$ ramp rate and was held at that temperature for 5 $\min$. The injector and detector temperatures were 230 and $240^{\circ} \mathrm{C}$, respectively. The injection volume of the sample was $1.0 \mu \mathrm{L}$ diluted in $n$-hexane. The sample was injected using a split ratio of 1:50. The Gas Chromatography/Mass Spectrometry (GC-MS) analysis of the oil was carried out in Thermo Scientific Trace Ultra GC interfaced with a Thermo Scientific ITQ 1100 Mass Spectrometer fitted with TG-5 fused silica capillary column $(30 \mathrm{~m} \times 0.25 \mathrm{~mm}$ i.d., $0.25 \mu \mathrm{m}$ film thickness) using above stated oven temperature program. The carrier gas was helium at $1.0 \mathrm{~mL} / \mathrm{min}$. The injector temperature was $230^{\circ} \mathrm{C}$ and the injection volume $0.1 \mu \mathrm{L}$ prepared in $n$-hexane. The sample was injected using a split ratio of 1:50. MS were taken at $70 \mathrm{eV}$ with mass scan range of 40-450 amu. The GC and GC/MS parameters were those reported earlier (Joshi, 2011; Joshi, Badakar, \& Kholkute, 2011a; Joshi, Badakar, Kholkute, \& Khatib, 2011b; Joshi \& Sharma, 2014).

\section{Identification of the compounds}

Identification of constituents were done on the basis of Retention Index (RI, determined with reference to homologous series of $n$-alkanes $\mathrm{C}_{\mathbf{8}}-\mathrm{C}_{25}$ under identical experimental conditions), MS library search NIST 08 MS Library (Version 2.0 f; Thermo Fisher Scientific Austria) and WILEY MS 9th Edition (Thermo Fisher Scientific Austria), and by comparing with the MS literature data (Adams, 2007) and co-injection of available authenticated samples purchased from Sigma-Aldrich, India ( $\geqslant 98 \%$ purity). The relative amounts of individual components were calculated based on the GC peak area (FID response) without using a correction factor.

\section{Results and Discussion}

Twenty-six compounds were characterized and identified according to their mass spectra and their relative retention indices determined on a non-polar stationary phase capillary column, comprising $98.9 \%$ of the total oil constituents. The compounds identified are listed in Table 1 in the order of their elution from the TG-5 column (Fig. 1 ), along with the percentage composition of each component and its retention index.

Table 1. Chemical composition of the essential oil of Ocimum tenuiflorum

\begin{tabular}{|l|l|l|l|}
\hline Compound & RI & $\mathbf{\%}$ & Identification \\
\hline$\alpha$-Pinene & 918 & 0.2 & RI, MS \\
\hline Camphene & 929 & 0.1 & RI, MS \\
\hline Sabinene & 947 & $\mathrm{t}$ & RI, MS \\
\hline$\beta$-Pinene & 951 & 0.1 & RI, MS \\
\hline$p$-Cymene & 992 & $\mathrm{t}$ & RI, MS \\
\hline Limonene & 996 & 0.2 & RI, MS \\
\hline Linalool & 1069 & 0.5 & RI, MS \\
\hline Camphor & 1123 & 0.1 & RI, MS, CI \\
\hline Borneol & 1147 & 2.4 & RI, MS, CI \\
\hline Terpin-4-ol & 1160 & 0.1 & RI, MS \\
\hline$\alpha$-Terpineol & 1177 & $\mathrm{t}$ & $\mathrm{RI}, \mathrm{MS}$ \\
\hline Methyl chavicol & 1185 & $\mathrm{t}$ & $\mathrm{RI}, \mathrm{MS}, \mathrm{CI}$ \\
\hline$\alpha$-Cubebene & 1368 & $\mathrm{t}$ & $\mathrm{RI}, \mathrm{MS}$ \\
\hline Eugenol & 1379 & 0.9 & $\mathrm{RI}, \mathrm{MS}, \mathrm{CI}$ \\
\hline$\alpha$-Copaene & 1399 & 1.9 & $\mathrm{RI}, \mathrm{MS}$ \\
\hline$\beta$-Bourbonene & 1410 & 0.2 & $\mathrm{RI}, \mathrm{MS}$ \\
\hline$\beta$-Cubebene & 1417 & 0.1 & $\mathrm{RI}, \mathrm{MS}$ \\
\hline$\alpha$-Elemene & 1419 & 0.5 & $\mathrm{RI}, \mathrm{MS}$ \\
\hline Methyl eugenol & 1442 & 82.9 & $\mathrm{RI}, \mathrm{MS}, \mathrm{CI}$ \\
\hline$\beta$-Caryophyllene & 1453 & 4.1 & $\mathrm{RI}, \mathrm{MS}, \mathrm{CI}$ \\
\hline$\beta$-Gurjunene & 1464 & $\mathrm{t}$ & $\mathrm{RI}, \mathrm{MS}$ \\
\hline$\alpha$-Humulene & 1493 & 0.2 & $\mathrm{RI}, \mathrm{MS}$ \\
\hline Germacrene D & 1525 & 2.3 & $\mathrm{RI}, \mathrm{MS}$ \\
\hline Germacrene A & 1553 & 0.7 & $\mathrm{RI}, \mathrm{MS}$ \\
\hline Cubebol & 1564 & 0.3 & $\mathrm{RI}, \mathrm{MS}$ \\
\hline$\delta$-Cadinene & 1574 & 1.1 & $\mathrm{RI}, \mathrm{MS}$ \\
\hline Monoterpene hydrocarbons & 0.6 & \\
\hline Oxygenated monoterpenes & 3.1 & \\
\hline Sesquiterpene hydrocarbons & 11.1 & \\
\hline Oxygenated sesquiterpene & 0.3 & \\
\hline Phenyl derivatives & & 83.8 & \\
\hline Total identified & & 98.9 & \\
\hline
\end{tabular}

$\mathrm{RI}=$ Retention index relative to $\mathrm{C}_{8}-\mathrm{C}_{25} n$-alkanes on $\mathrm{TG}-5$ column, MS=NIST and Wiley library and the literature, $\mathrm{t}=$ trace $(<0.1 \%)$, $\mathrm{CI}=$ Co-injection of authentic samples.

The main constituent was identified as methyl eugenol $(82.9 \%)$. The other minor constituents were $\beta$-caryophyllene $(4.1 \%)$, borneol $(2.4 \%)$, germacrene D (2.3\%) and $\alpha$-copaene (1.9\%). Phenyl derivative (83.8\%) constituents were the prominent group of compounds followed by sesquiterpene hydrocarbons (11.1\%), oxygenated monoterpenes, (3.1\%), monoterpene 


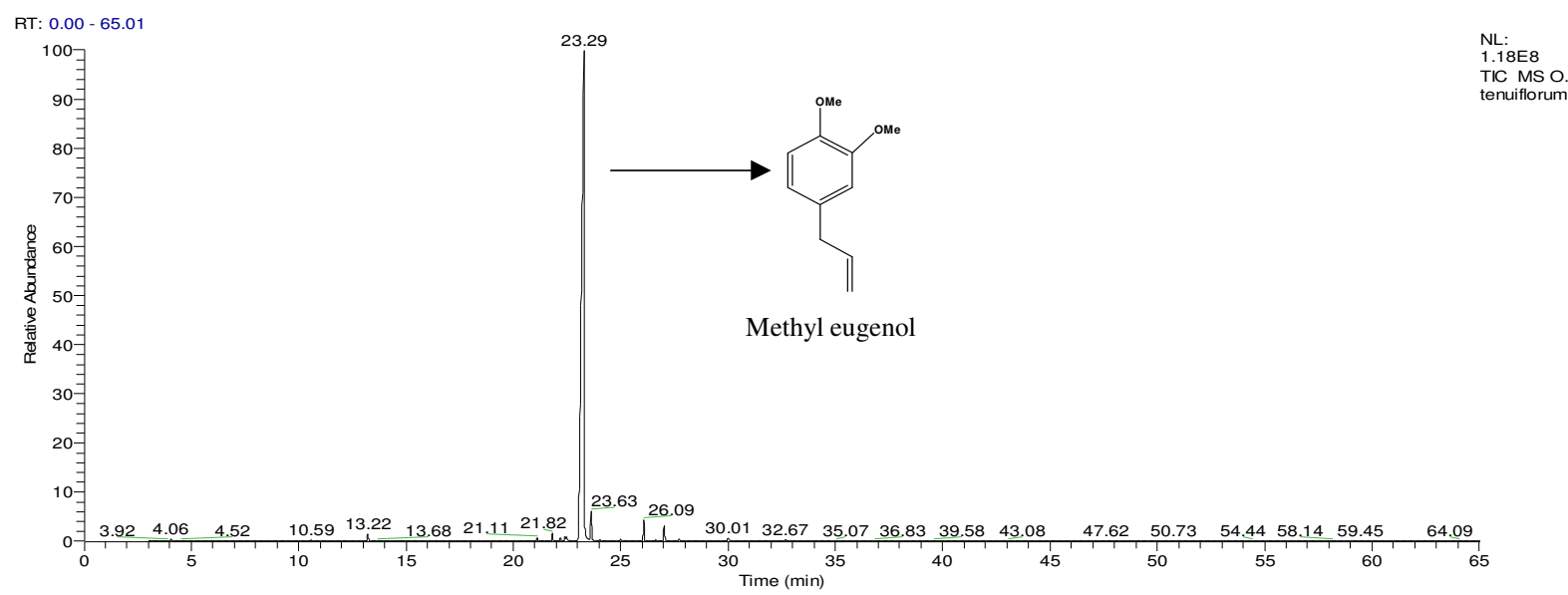

Fig. 1 GC-TIC chromatogram of the essential oil of Ocimum tenuiflorum

hydrocarbons $(0.6 \%)$ and oxygenated sesquiterpene $(0.3 \%)$.

The compound methyl eugenol has been reported in varying amounts along with diverse chemotypes from different regions (Bhattacharya et al., 1996; Kothari et al., 2005; Joshi, 2013a; Awasthi \& Dixit, 2007; Gbolade \& Lockwood, 2008). It is interesting to note that chemotypes containing other compounds have also been reported (Khan et al., 2010; Kicel et al., 2005; Machado et al., 1999; Brophy et al., 1993; Pino et al., 1998).

This report presents low amount of methyl eugenol as compared to the earlier report (Joshi, 2013a) from the essential oil of 0 . tenuiflorum collected from North West Karnataka, India. The quantitative differences in the major constituents of plant could be due to the season, climate or soil conditions.

\section{Acknowledgments}

The author is grateful to the Indian Council of Medical Research (ICMR), New Delhi, India for providing necessary facilities and thanks to Miss Vijaylaxmi Badakar, Lab Assistant, Department of Phytochemistry, Regional Medical Research Centre (ICMR), Belgaum for collection and extraction of essential oil.

\section{References}

Adams, R. P. (2007). Identification of Essential Oil Components by Gas Chromatography/Mass Spectroscopy. Illinois, USA: Allured Publishing Corporation, Carol Stream.

Awasthi, P. K., \& Dixit, S. C. (2007). Chemical compositions of Ocimum sanctum Shyama and Ocimum sanctum Rama oils from the plains of Northern India. Journal of Essential Oil Bearing Plants, 10, 292-296. http://dx.doi.org/10.1080/0972060X.2007.10643557

Bhargava, K. P., \& Singh, N. (1981). Antistress activity of Ocimum sanctum Linn. Indian Journal of Medical Research, 73, 443-451. PMid:7275241

Bhattacharya, A. K., Kaul, P. N., \& Rajeswara Rao, B. R. (1996). Essential oils of Ocimum gratissimum L. and Ocimum tenuiflorum L. (syn. Ocimum sanctum L.) grown in Andhra Pradesh. Indian Perfumer, 40, 73-75.

Brophy, J. J., Goldsack, R. J., \& Clarkson, J. R. (1993). The essential oil of Ocimum tenuiflorum L. (Lamiaceae) growing in Northern Australia. Journal of Essential Oil Research, 5, 459-461. http://dx.doi.org/10.1080/10412905.1993.9698260

Devi, P. U. (2001). Radioprotective, anticarcinogenic and antioxidant properties of the Indian holy basil, Ocimum sanctum (Tulasi). Indian Journal of Experimental Biology, 39, 185-190.

Gbolade, A. A., \& Lockwood, G. B. (2008). Toxicity of Ocimum sanctum L. essential oil to Aedes aegypti larvae and its chemical composition. Journal of Essential Oil Bearing Plants, 11, 148-153. http://dx.doi.org/10.1080/0972060X.2008.10643611

Godhwani, S., Godhwani, J. L., \& Vyas, D. S. (1987). Ocimum sanctum: an experimental study evaluating its antiinflammatory, analgesic and antipyretic activity in animals. Journal of Ethnopharmacology, 21, 153-163. http://dx.doi.org/10.1016/0378-8741(87)90125-5

Joshi, R. K. (2011). GC/MS analysis of the essential oil of Senecio belgaumensis flowers. Natural Product Communications, 6, 1145-1146. PMid:21922922

Joshi, R. K. (2013a). Chemical composition, in vitro antimicrobial and antioxidant activities of the essential oils of Ocimum gratissimum, 0 . Sanctum and their major constituents. Indian Journal of Pharmaceutical Sciences, 75, 457-462. http://dx.doi.org/10.4103/0250-474X.119834 PMid:24302801 PMCid:PMC3831728

Joshi, R. K. (2013b). Chemical constituents and antibacterial property of the essential oil of the roots of Cyathocline purpurea. Journal of Ethnopharmacology, 145, 621-625. http://dx.doi.org/10.1016/j.jep.2012.11.045 PMid:23220198

Joshi, R. K., \& Badakar, V. (2012). Chemical composition and in vitro antimicrobial activity of the essential oil of the flowers of Tridax procumbens L. Natural Product Communications, 7, 941-942. PMid:22908588

Joshi, R. K., \& Sharma, A. K. (2014). Cis-ocimenone chemotype essential oil of green mint (Mentha viridis L.) from Western 
Ghats region of North West Karnataka, India. Plant Science Today, 1, 10-12. http://dx.doi.org/10.14719/pst.2014.1.1.7

Joshi, R. K., Badakar, V., \& Kholkute, S. D. (2011a). Carvacrol rich essential oils of Coleus aromaticus (Benth.) from Western Ghats region of North West Karnataka, India. Advances of Environmental Biology, 5, 1307-1310.

Joshi, R. K., Badakar, V. M., Kholkute, S. D., \& Khatib, N. (2011b). Chemical composition and antimicrobial activity of the essential oil of the leaves of Feronia elephantum (Rutaceae) from North West Karnataka. Natural Product Communications, 6, 141-143. PMid:21366066

Karthikeyan, K., Ravichadran, P., \& Govindasamy, S. (1999). Chemopreventive effect of Ocimum sanctum on DMBA-induced hamster buccal pouch carcinogenesis. Oral Oncology, 35 , 112-119. http://dx.doi.org/10.1016/S1368-8375(98)00035-9

Kathiresan, K., Guanasekan, P., Rammurthy, N., \& Govidswami, S. (1999). Anticancer activity of Ocimum sanctum. Pharmaceutical Biology, 37, 285-290. http://dx.doi.org/10.1076/phbi.37.4.285.5801

Khan, A., Ahmad, A., Akhtar, F., Yousuf, S., Xess, I., Khan, L. A., \& Manzoor, N. (2010). Ocimum sanctum essential oil and its active principles exert their antifungal activity by disrupting ergosterol biosynthesis and membrane integrity. Research in microbiology, 161, 816-23. http://dx.doi.org/10.1016/j.resmic.2010.09.008 PMid:20868749

Kicel, A., Kurowska, A., \& Kalemba, D. (2005). Composition of the essential oil of Ocimum sanctum L. grown in Poland during vegetation. Journal of Essential Oil Research, 17, 217-219. http://dx.doi.org/10.1080/10412905.2005.9698880

Kothari, S. K., Bhattacharya, A. K., Ramesh, S., Garg, S. N., \& Khanuja, S. P. S. (2005). Volatile constituents in oil from different plant parts of methyl eugenol-rich Ocimum tenuiflorum L. f. (syn. O. sanctum L.) grown in South India. Journal of Essential Oil Research, 17, 656-658. http://dx.doi.org/10.1080/10412905.2005.9699025

Machado, M. I. L., Silva, M. G. V., Matos, F. J. A., Craveiro, A. A., \& Alencar, J. W. (1999). Volatile constituents from leaves and inflorescence oil of Ocimum tenuiflorum L. f. (syn. $O$. sanctum L.) grown in Northeastern Brazil. Journal of Essential Oil Research, 11, 324-326. http://dx.doi.org/10.1080/10412905.1999.9701145

Mukherjee, R., Das, P. K., \& Ram, G. C. (2005). Immunotherapeutic potential of Ocimum sanctum Linn. bovine subclinical mastitis. Research in Veterinary Science, 79, 37-43. http://dx.doi.org/10.1016/j.rvsc.2004.11.001 PMid:15894022

Pandey, B. P. (1990). Economic Botany. Ramnagar, New Delhi: Chand and Company Ltd., p. 294.

Pino, J. A., Rosado, A., Rodriguez, M., \& Garcia, D. (1998). Composition of the essential oil of Ocimum tenuiflorum $\mathrm{L}$. grown in Cuba. Journal of Essential Oil Research, 10, 437-438. http://dx.doi.org/10.1080/10412905.1998.9700937

Prashar, R., Kumar, A., Banerjee, S., \& Rao, A. R. (1994). Chemopreventive action by an extract from Ocimum sanctum on mouse skin papillomagenesis and its enhancement of skin glutathione-S-transferase activity and acid soluble sulfhydryl level. Anticancer Drugs, 5, 567-572. http://dx.doi.org/10.1097/00001813-199410000-00008 PMid:7858289

Seth, S. D., Johri, N., \& Sundaram, K. R. (1981). Antispermatogenic effect of Ocimum sanctum. Indian Journal of Experimental Biology, 19, 975-976. PMid:7309144

Singh, S., \& Majumdar, D. K. (1997). Evaluation of anti-inflammatory activity of fatty acids of Ocimum sanctum fixed oil. Indian Journal of Experimental Biology, 35, 380-383. PMid:9315239

Singh, S., Malhotra, M., \& Majumdar, D. K. (2005). Antibacterial activity of Ocimum sanctum L. fixed oil. Indian Journal of Experimental Biology, 43, 835-837. PMid:16187537

Sirkar, N. N. (1989). Pharmacological Basis of Ayurvedic Therapeutics. In: C. K. Atal \& B. M. Kapoor (Eds.), Cultivation and utilization of medicinal plants. New Delhi: PID, CSIR.

Yadav, S. R., \& Sardesai, M. M. (2002). Flora of Kolhapur District. Kolhapur: Rajhuns Printing Press, p. 382. 